\title{
THE HISTORICAL CRYSTALLIZATION OF A COMPOSER'S AND INDIVIDUAL MUSICAL AUTHORSHIP PHENOMENA IN THE EUROPEAN CULTURE OF THE RENAISSANCE
}

\section{Iryna Konovalova}

\section{INTRODUCTION}

The urgent task of an art criticism in a difficult conditions of contemporary artistic and historical development is the theoretical comprehension of the musical culture phenomena, which gained the meaning of a humanitarian significance and represented the stable traditions of a human spirituality. In this context, the study of the composer's phenomenon which has become a symbol of an artistic and aesthetic search for creative individuality in the European tradition, seems to be fundamentally important vector of a modern musical science.

The concept of an individual music authorship in the discourse of contemporary art also needs to be systematically justified. This concept is seen as a valuable sphere of an artistic reflection in the written musical culture, a unique phenomenon of a social existence, which arose in the European civilization continuum in connection with the creative activity of a musiciancreator, the realization of his intellectual-spiritual and artistic qualities.

The creative figure of a composer, the universalism manifestation by the musical concepts creator, arouses persistent and long lasting interest in a musical-theoretical thought. In the field of a modern musicology, research attention is being extended to an individual and personal determinants of creativity, the nature of cultural being and the author's will as the music creator.

It should be noted that "focused on the problems of the author-creator, the modern autorological paradigm reveals an interdisciplinary research vector and demonstrates an intention for openness in a space of humanitarian thought, including the comprehension of the musical authorship sphere" development of a certain aspects of this problem are reflected in the musicology works of N. Gerasimova-Persidska, L. Ivanova, L. Kazantseva, V. Kholopova and others.

At the same time, despite the existing experience of studying the composer's tradition and musical authorship creativity in European culture, a significant number of important aspects still remain unstrucked in the art and cultural thought. Comprehension of the cultural essence and specificity of the

\footnotetext{
${ }^{1}$ Konovalova I. (2018). The Composer Phenomenon in the 20th century European Music Cultural Space: Modes of Theoretical Understanding. Kharkiv: TOV "Planeta-Print”. P. 87.
} 
composer's phenomenon in the discourse of an authorship, seems to be a significant area of a scientific research, still explored insufficiently. Due to the lack of these issues development, the purpose of the proposed research is to understand the peculiarities of a historical crystallization of a composer's phenomenon and the model of an individual musical authorship in the European cultural consciousness of the Renaissance era.

The following study problematics aimed the realization of the next tasks:

1) to reveal the determinants of a historical emergence of the composer's phenomenon and the phenomenon of a musical authorship in the context of a humanistic Renaissance tendencies;

2) to highlight a composer's semantic role in the processes of cultural formation and the musical picture of the Renaissance world modeling;

3) to outline the specifics of an artistic system "author - creativity composition" representation in the musical art of the Renaissance.

The stated goals and objectives required the use of a comprehensive methodological approach based on a set of general scientific and specific methods. Among the leading scientific methods are: historical, which serves to reveal the evolution stages of the composer's phenomenon and the phenomenon of an authorship, contributes to the nature of continuity and innovations understanding in their development; dialectical, aimed at illuminating the universalism manifestations in the composer's cultural figure development; phenomenological, aimed at understanding the concept of an individual musical authorship as a culture phenomenon.

\section{Sociocultural determinants of a composer's and musical authorship phenomena formation during the Renaissance}

The Renaissance is the most important stage of a European culture spiritual evolution, determined by an anthropocentric worldview paradigm. This historic period, marked by humanistic pathos, is characterized by a deep interest in the human's spiritual world, recognized as the center of the world, his highest power, which participates in a world-modeling, acts as a universal, harmonious and holistic personality ${ }^{2}$. Cultural and personal universalism, intellectual-spiritual principle, harmony in understanding the essence of phenomena become symbols of time, its spiritual-value context.

New worldviews and innovative tendencies in the socio-cultural realm and system of an artistic Renaissance thinking, which incorporated the experience of an ancient and medieval artistic traditions, contributed to the intensification of an art's desacralization and secularization, and were accompanied by an increase of a secular contexts role, which developed in a humanistic tendencies.

\footnotetext{
${ }^{2}$ Semenov O. (1978). The relationship of an author, composition and viewer (reader, listener) // Muzikal'noye iskusstvo i nauka, vol. 3. Musical art and science. Moscow: Muzika. P. 97.
} 
During the Renaissance, the world of general importance universals and categories of art enriches by the concepts of an "author", "artist", "creator", as well as "composer" which have received the status of a spiritual-axiological constants. At the forefront of an art history of this period emerges the concept of individuality, the attribute properties of which are originality, uniqueness, originality, virtuosity ${ }^{3}$. The unifying semantic center of the above concepts, crystallized in the depths of European artistic consciousness, is creativity - the productive activity, sphere of a creative performance of a subject.

According to the Renaissance humanistic setting, creativity was interpreted as a personal process. As a result, the Renaissance culture opened up a whole epoch of a personal world of an artcreation in the European civilization space, which gradually freed itself from the craft's dependence and finds a personalized expression, allowing to express artistically the inner world of a human - the microcosm and center of a world formation. The role and importance of an artist as a subject of creation, which expands the picture of a human being and a sphere of an individual possibilities, in this period is being rethought and taken to a new level. The artistic objectification of an artist intentions, his self-realization and individual expression becomes selfimportant and meaningful, since the creations of this era are imbued with an understanding of a special mission and role of a human-creator's personality as an earth embodiment of the Divine principle ${ }^{4}$.

Belief in an infinite person possibilities, understanding of its self-worth, spiritual and physical perfection, infinity of an internal space contributed to the high exaltation in various spheres of an artistic creativity. First of all, in the visual arts, which consistently revealed Renaissance ideas and clearly depicted a person with aspirations, as well as a literary and poetic realm capable to embody with a conceptual accuracy the features of a new free and active personality, marked by the traits of universalism ${ }^{5}$. Individual-personal meaning, intuitive and intellectually-sensory experience, relations with social reality, reflected in the artist's worldview and feelings, became determinants of his work ${ }^{6}$.

The sociocultural transformations of the Renaissance era have found a variety of reflections in the musical arts and affected its adepts. Being the most psychologized artistic realm, the bearer of an intellectual and spiritual principles, musical art of the Renaissance culture is filled with a new figurative content and finds emotional immersion. In this area, the aesthetic

\footnotetext{
${ }^{3}$ Batkin L. (1989). Italian Renessance in a search of personality. Moscow: Nauka. P. 3-4.

${ }^{4}$ Lozovoi V. (2007). Culture morphology: thesaurus. Kharkiv: Pravo. P. 48.

${ }^{5}$ Ibid. P. 48.

${ }^{6}$ Ghoral'skij A. (2002). Creativity theory / Pereklad z pol's'koji; O. Ghirnyj. L'viv: Kamenjar; Varshava: Universitas Rediviva. P. 12.
} 
functions are highlighted, the individual principle is outlined. The world of human feelings, reflected in an intonational images, receives the status of an artistic value.

Under the influence of a worldview and artistic processes of the Renaissance, a reorientation in music status understanding is pointed out: it ceases to be perceived as a craft (according to the medieval ideas) and is already interpreted as a valuable free art and a form of a creative activity. The cosmological concept of the music interpretation, dominant in the Middle Ages culture, receives an anthropological interpretation during the Renaissance.

According to L. Shapovalova, - the very figure of a person in the Renaissance musical art "owes its birth to an era of anthropocentrism and formed under the sign of a secular humanistic consciousness. A person who thinks the whole world from the standpoint of its own being proclaims to be the crown of an universe" artist has recognized himself as a personality and, having linked himself to the spiritual horizon of being, has named the term "personality" as an... omensymbol <...> Instead, artists of a humanistic secular culture became an example of an individual art birth"8.

The "minor" role of music in the Renaissance art system (the primacy in which was given to the visual arts, painting in particular) determined the corresponding social status of musician in comparison with sculptors, artists, and philosophers. At the same time, the position of the musical compositions creator, unlike the era of the Middle Ages, significantly increased.

In the cultural space of the Renaissance, the standards of professional music practice are being formed, the foundations of creative psychology and the means of an artistic expression are being formed, and the fields of improvisation and musical composition are gradually distancing themselves. Simultaneously with the appearance of a creative figure of the composerauthor, the figures of the performer and the listener appeared, their functions differentiated. This serves as an evidence of a cultural crystallization of the triadic system of musical communication: composer - performer - listener. At the same time, "simultaneously with the establishment of a new norms and skills of crafts, the individual expressiveness of the master performer increases" $"$.

${ }^{7}$ Shapovalova L. (2001). About two types of personality: to musical reflection definition // Muzykaln'aya kult'ura khrystyanskogho mira: materialy mezhdunar. nauchnoi konferenciyi. The musical culture of the Christian world. Rostov n/D: izdatel'stvo Rostovskoj gos. konservatoriyi im. S. V. Rakhmaninova. P. 135.

${ }^{8}$ Ibid. P. 135.

${ }^{9}$ Asaf'ev B. (1971). Musical form as a process. Kniga 1-2. Leninghrad: Music. P. 154. 
A significant characteristic of the Renaissance culture is the formation of a theoretical art concept, which also covers the fields of philosophy, aesthetics, and music theory. An intellectual and creative efforts of musicians aimed at the world's picture reflection, their search for a new means of an artistic poetics, genre concepts and music structural regularities, were accompanied by a systematic justification of a musical processes and phenomena, as well as generalization of practical skills in this field.

Within the expansion of a music reflection field, crystallization of the categorical apparatus takes place, also with the formation of basic terms and concepts of a musical art. There is an increasing focus on the disclosure of an ontological aspects of musical creativity and performance from the prominent representatives of Renaissance theoretical thought (K. Bortolo, L. Valla, N. Listenii, M. Padouansky, J. Tinctoris, A. Fuldsky, Tsarlino, etc. $)^{10}$. Particularly important in this sense seems to be an isolation of the initiative and creative components, the fact of novelty, as well as the beginnings of an individual musical style in the composer's practice, conscious of being an author - that "....who wrote some new cantus" (J. Tinctoris, 1474) ${ }^{11}$.

Changing modes of a musical understanding and hermeneutics of its phenomena during the Renaissance cultural continuum, enshrined in the theoretical treatises of the most prominent musicians-thinkers of the time, had contributed to the establishment of a composer's individuality concept. The justification of a new music existence in the form of completed and artifacted authorship compositions is quite demonstrative. The idea of an improvised and fixed ("res facta") compositions differentiating, proposed by the prominent theorists J. Tinctoris, becomes crutial. The related concept was put forward in the treatise "Musica" by N. Listenii (1537), which proposes the division of music into practical, performed ("musica practica"), which is regarded as an activity isolated within its limits, made ("musica poetica"), and immortalized even after the author's death as a result of his creation - "Opus refectum et absolutum"12.

The duality of judgments about an aesthetic epoch ideal, inherent to the Renaissance era, ascends from an ancient understanding of a harmony and perfection on the one hand, and the Renaissance vision of the Divine beauty, on the other hand, and "lies in a basis of a strict style that represents different shades of a contemplative principle", and also determines the specifics of a

${ }^{10}$ Shestakov V. (1975). From ethos to affect. The History of Musical Aesthetics from Antiquity to the 18th Century. Moscow: Muzika.

11 Keldysh Yu. V. (ed) (1991). Musical Encyclopedia Dictionary. Moscow: Soviet encyclopedia.

${ }^{12}$ Cherednichenko T. (1989). Trends of Contemporary Western Musical Aesthetics. Moscow: Muzika. P. 142. 
music - aesthetic understanding of the era's sound standard, which reflected itself in the canons and strict polyphonic writing technique" ${ }^{\text {"13 }}$. Instead, the vocal-choral music of the Renaissance era for the following centuries listeners appears as "the only sublime contemplative strict style, which is imbued with the light of faith, irrespectively to the content and genre varieties"14.

In combination of a new emotional content "with an expression of an intellectualism in the aesthetics and mastery of a complex polyphonic forms", Livanova sees the peculiarity of the Renaissance musical humanism manifestations ${ }^{15}$. Actually, an artistic integrity and organization of the Renaissance music is based on the laws of a polyphonic development. The reliance on rhetorical modes, inherent to a Middle Ages music genres, has been gradually lost during the Renaissance. However, the polyphonic type of thinking remained dominant in both religious and secular musical spheres until almost the middle of the eighteenth century - the period of classicism.

The secularization tendencies inherent to the Renaissance have outlined the convergence of two types of cultural consciousness - the spiritual and the secular, leading to a further predominantly secular vector of a musical art evolution. In the course of a European art evolution, there is a tendency to move from the priority of a musical sacred Word to the gradual liberation of the latter from a verbal determination. An inherent coexistence of a "spiritual - secular" dichotomy gained its expression in the works of the Renaissance period composers. This contributed to a theme and imagery of an artistic creativity expansion, in the organic combination of the liturgical and secular music genres. Numerous compositions of a secular genres (for example, madrigal), along with their applied function of an exalted character, had spiritual and philosophical content.

During the Renaissance, both secular and ecclesiastical music layers were embraced by a single sublime, meditative character, and, like the medieval sacred space genres, relied mostly on Gregorian melodies. The freedom to involve an intonational material of a spiritual music in the samples of a secular genres is maintained throughout the sixteenth century: madrigals, polyphonic songs, organ richerkars, canzons, fantasies, had been actively assimilated Gregorian elements, "shaping" a future baroque rhetorical

${ }^{13}$ Kaloshyna Gh. (2001). Christian subjects and problems of the genre evolution of French opera and oratoria: from the beginnings to the twentieth century // Muzykal'naya kul'tura khrystyanskogho mira: materialy mezhdunar. nauchnoi konferenciyi. The musical culture of the Christian world. Rostov n/D: izdatel'stvo Rostovskoj gosudarstvennoy konservatoriyi im. S. V. Rakhmaninova. P. 297.

${ }^{14}$ Ibid. P. 297.

15 Livanova T. (1986). The history of Western European music until 1789. vol. 1: Ot antichnosti k XVIII veku [From Antiquity to the 18th Century]. Moscow: Music. P. 73. 
formulas. On the contrary, masses have transformed the secular melos in their musical texture, radically changing its rhythmic timing ${ }^{16}$.

Increasing role of the secular musical tradition affected the dominance of a vocal lyrics, associated with the folklore poetic basis (embodied in the genres of an Italian frottola and villanella, French chanson), examples of knight aristocratic poetry, as well as the figuratively-poetic world of the poetshumanists (Petrark etc.). Reliance on the "high lyrics" texts is reflected in the formation of the madrigal tradition - a genre of a late Renaissance, formed in the courtier-aristocratic sphere. The desire to express various emotional shades and personal experiences, the transmission of emotional and sensual expression in the lyrical madrigal genre, reproduced in the melodic individualization of the polyphonic voice texture, as well as the compositional and rhythmic freedom of their works, their desire of an improvisation.

The reflection of an individual composer's self-understanding is noticeable in the enrichment of a musical and expressive means, the expansion of an intonation palette with the sonorous elements, and sharpened sounds (through the introduction of chromaticisms). The degree of an author's self-expression freedom was emphasized by the lack of cantus firmus in Madrigal and the usage of a fictional melos that reflected the composer's creative will ${ }^{17}$.

Appealing to the secular imagery, the lyrical genre sphere of madrigals with its predominantly love theme, was a characteristic phenomenon of the Renaissance composer's practice (the emergence of a numerous collections serves as evidence). The fact of appealing to the madrigal is observed in the works of a large-scale Renaissance artists, recognized by the papacy - holders of an official status of an ecclesiastical Catholic composers, including P. da Palestrina, Arcadelt, Willaert and others.

However, despite the general socio-cultural dynamics, a radical change in the picture of the world and worldview vector from the Middle Ages to the Renaissance, the processes of change in the musical culture nature, the development of musical thinking and language had their own specificity.

In parallel with a secular development line, in the Renaissance musical art (in comparison with other varieties of an artistic creativity), the significant role of the spiritual-religious sphere, canonical practice, dependence on the medieval canons of a musical thinking, the corresponding compositional logic and specifics of a linguistic development are revealed.

The focus on the theocentric picture of the world and the tradition of a sacred genres, which reflect the structure of religious consciousness in a musical composition, was preserved. This explains the semantic role of

\footnotetext{
${ }^{16}$ Simakova N. (1985). Renaissance vocal genres. Moscow: Muzika. P. 42.

${ }^{17}$ Gruber R. (1965). General History of Music. Moscow: Music. P. 267.
} 
spiritual genres in the system of the Renaissance music, the priority of polyphonic thinking that semantically connects the works of this era with the works of the Middle Ages masters. Despite the tendency to individualize the creative activity of an individual artist, the masters of the Renaissance, as in previous epochs (Antiquity and the Middle Ages), focused on a comprehensive world's reflection, the synthesis of collective and individual principles.

For the Renaissance music, "...the embodiment of one's own personal beginnings isn't intrinsic to everything and always"18. An extra-personal nature of imagery, thematics "neutrality", dominant in the practice of the polyphony masters of the $\mathrm{XV}^{\text {th }}$ century, also late $\mathrm{XVI}^{\text {th }}$ century madrigalists, could be explained by an influence of a medieval traditions, and by the continuation of the "gothic line" in the Renaissance art, also by a special musical art existence conditions (mainly in the sacred or courtly-secular space). The non-personal principle manifestation in the Renaissance musical art (as a constant sign of a medieval thinking, indicated by an influence of a religious-canonical practice), is manifested at different levels of an artistic integrity of a composition.

The medieval consciousness inertia in Renaissance music practice is emphasized by the "insufficiency" of the original final intonational idea, the reliance on the principle of quoting a borrowed music-thematic material (with its subsequent polyphonic processing), the transfer of accents on the mastery and inventiveness in a creative structure ${ }^{19}$. However, within the given conditions, outstanding composers like O. Lasso, Palestrina, etc. showed a tendency to an imaginative expression and artistic independence.

\section{The historical specificity of an individual musical authorship paradigm formation and the composer's phenomenon during the Renaissance}

The classical concept of an individual authorship is formed in the context of the Western European Renaissance culture development under the new socio-cultural conditions and practices of text distribution, including musical one (through a sheet music). This specificity is defined by "the constitution of the subject's binary opposition and assigned to him object, which acts as a participant of a paradigmatic figure and correlates an effective process to the subject as a process agent" ${ }^{\text {"20 }}$.

\footnotetext{
${ }^{18}$ Livanova T. (1986). The history of Western European music until 1789. Vol. 1 : Ot antichnosti k XVIII veku [From Antiquity to the 18th Century]. Moscow: Music. P. 75.

${ }^{19}$ Ibid. P. 75.

${ }^{20}$ Grom'jak R., Kovaliv Ju., Teremko V. (ed) (2007). Literary references dictionary. Kyiv: VC “Akademija”. P. 45.
} 
Cultural awareness of an "authorship as an appropriate category for a creative, extraordinary personality, emerged... at the stage of transition from a folk-collective to an individual form of consciousness"21. The reorientation on an individual creativity authorship concept took place parallelly in all kinds of arts. In the creative practice of the late Renaissance, "...the identity of an author as a personality begins to come to the fore, and the artistic world has been subjected increasingly",22.

In an individual authorship paradigm, the problems of originality, authenticity and value of an art creation - a creative product, preserved and distributed in cultural forms - are actualized. Fixation of an authorship, an indispensable attribute of which is individuality, becomes a special sociocommunicative act and a sign of a cultural artifact - a work of art that distinguishes the artist as a subject of creativity. Indication of an author's name, creation to its creator affiliation marking characterizes the work as authorial.

Composing as a kind of a musical practice in the European artistic thinking system, as well as specific form of an intellectual and artistic activity and culture itself, arises from a craft - an auxiliary kind of occupation (composition). During the Renaissance, this area is transformed into a creative profession and establishes as a form of an individual musical authorship. In comparison with a folklore or spiritual-canonical practice, a significant factor in the system of an individual authorship and musical composer's creativity is played by a personal factor, creative ingenuity during the work with an intonational material, which presupposes a dialectical relation to the tradition in the system of oppositions "preservation - updating", "adaptationmodification" 23 .

The most important determinant of an individual music authorship paradigm crystallization and assertion during the Renaissance, is the tendency to textualize European musical culture, which has emerged as "one of the main sources of separation of the creative function in the music profession and the establishment of a new discursive model of European art, connected with an individual composer's music",24.

${ }^{21}$ Malkov S. (2010). Concepts of an authorship and tasks of an educational system // Chelovek vchera i seghodnja: mezhdyscyplynarnye issledovanyja. Man yesterday and today: interdisciplinary research vol. 4. Moscow: Institut filosofyy RAN, pp. 39-50. P. 41.

${ }^{22}$ Semenov O. (1978). The relationship of an author, composition and viewer (reader, listener) // Muzikal'noye iskusstvo i nauka, vol. 3. Musical art and science. Moscow: Muzika, pp. 78-105. P. 100.

${ }^{23}$ Konovalova I. (2018). The Composer Phenomenon in the 20th century European Music Cultural Space: Modes of Theoretical Understanding. Kharkiv: TOV "Planeta-Print. P. 100.

${ }^{24}$ Ivanova L. (2006). Composer: essays on the history of the professional formation. (PhD Thesis). Moskva: MGhK im. P. Y. Chajkovskogo. P. 13. 
Written fixation of a creativity results provided an opportunity to consolidate the status of a composition as an important document of the era, artifact of a culture and determined the alienation of the composition from its author. This process gave rise to the formation of a new forms in the system of musical communication (author - performer - audience), which influenced the development of composer and performing traditions in general. The emergence of a sheet music contributed to the development of a composer's professionalism, as well as to approval of a musician-creator in a new quality and role as a key figure of a musical art.

The dissemination and reproduction through the system of notation of a newly created musical texts was caused by an urgent need and the growing scale of a musical practice related to an internal development of the leading musical realms during the Renaissance- church, singing, minestral and secular, which formed in an urban aristocratic environment ${ }^{25}$.

The paradigm shift from a collective to an individual form of an authorship, which took place in the European consciousness of the Renaissance, the growth of secular mode in culture, the desire of free and emotionally colored life embodiment in a musical art (in parallel with visual, monumental and dramatic arts) was marked by the emergence of a creative figure of a new type - a composer, music creator who asserts himself as an author, composer-author, who performs purposeful musical and creative activity, resulting in an artistic monuments - fixed and spiritually elevated compositions written in accordance with the laws of beauty and sophisticated craftsmanship, which perpetuates the author's creative personality in the art.

During the Renaissance, composer as a social phenomenon becomes autonomous, gaining his own name and a greater cultural role, which determines the motivation for creativity and his personality disclosure. The atmosphere of the Renaissance, as an anthropocentric continuum, had a significant impact on the radical change in attitude to the composer in society, as well as the improvement of his socio-cultural status. In the context of a new humanistic value system, the composer's attitude to creativity is also changing.

As a result of a new written music essence, one realizes the value of a musical composition's author: composer's names become famous, worshiped, the figures of the musicians-creators attract the attention of historians, biographers and public consciousness of that time, they become heroes of a literary works, mentioned in the chronicles and ranked as a prominent personalities $^{26}$.

25 Ivanova L. (2006). Composer: essays on the history of the professional formation. (PhD Thesis). Moskva: MGhK im. P. Y. Chajkovskogo. P. 11.

${ }^{26}$ Ibid. P. 14. 
In the cultural conditions of the Renaissance, with its anthropocentric orientation, emphasized individual identity of an artist's world focusing, the composer, in accordance with the concept of a universal Renaissance personality, considered as a unique and volitional creative personality, endowed with a high creative potential and universal qualities, which creates himself and his own self being, focuses on a self-representation, individuality and originality of an intonational expression, ponders about his own artistic message.

According to L. Kiyanovska, - "The medieval composer-craftsman is replaced by the composer-thinker who... not only masks the canons, but also independently creates them, relying on the overall Universe values and spiritual understanding of the thing's essence" 27 .

A musical art creator is affirmed in the culture as a professional, who possesses professional skills, distinguishes by an individuality of an author's self-expression and receives a systematic special and comprehensive education in urban music centers (metrizes), and has multilateral knowledge in the field of music theory, and organ performance. This process took place in the system of views on creative activity as a professional act, characterized by its style.

The creator of the world's musical reflection presents his original worldview, his own intuitive and life-giving experience in artistic and figurative forms, and comprehends a new humanistic essence of the Renaissance cultural and historical era, embodying in his intonational work palette his inner aesthetic content, artistic and spiritual impulses. Artistic, sublime and earthy musical images created by a Renaissance music author, are full of harmony and beauty, they associated with a bright, joyful and inspired worldview, as well as high religious sentiment.

The updating of new forms and genres of a musical creativity and the growing professional skill of musicians helped to strengthen the composer's importance in a space of a cultural era, in which he appears in a functionally dual (musician-performer-composer) and triadic (composer-performertheoretician) qualities.

A composer positioning as an art works' author was largely facilitated by the emergence of an individual-style manner, which seen as an evidence of a new axiological relationships affirmation and personal qualities of the musician, indicated by the features of uniqueness, originality, and manifest themselves in a musical creation.

${ }^{27}$ Kyjanovs'ka L. (2012). Composer's image in society // Naukovyj visnyk Nacional'noji muzychnoji akademiji Ukrajiny im P.I. Chajkovs'kogho. Scientific Bulletin of the National Music Academy of Ukraine named after P.I. Tchaikovsky. Vol. 75. Kyiv: NMA. P. 29. 
According to O. Devyatova, - " “..the strengthening of a composer's professional position in the depths of a secular Renaissance culture led to a change of his functions and his status in earthly, secular space affirmation"28.

Thus, in a secular tradition context, a type of an artist who combines in one person the role of a creative aristocrat and a playful amateur musician is formed. The merger of a performer and music creator in one person led to a formation of a "playing composer" creative type ${ }^{29}$, which has spread in the subsequent epochs (Baroque and Classicism). The practice of a "playing composer" was an experience of a secular music playing in the courtlyaristocratic atmosphere, in the conditions of a palace hall and was based on the musician's own works. Artists of this type have realized their creative potential in the practice of improvisation, while demonstrating a high level of performing skills. The proficiency of a "playing composer" improvisation was determined by the accent on a creative figure of an artist, but not on the composition, still not fully fixed in the sheet music ${ }^{30}$.

At the same time, despite the growing role of an author's individualization in music (almost till the eighteenth century - the Era of Enlightenment, which focused on the aesthetic laws of classicism), personal manifestations in various fields of art and literature were restricted significantly. The authors' initiative of the creators was adjusted by the established artistic canons, aesthetics, style and genre norms. The composer's consciousness was mainly focused on the rhetorical type of creativity and already formed principles of musical thinking.

\section{Musical composition as a form of an artistic autorepresentation of a composer}

During the Renaissance, the idea of self-sufficiency, autonomy and significance of the results of the author's activity of the composer is formedcompositions considered as a main and ideal expression of the unique author's originality and as a sign of his artistic personality presence. In an imaginative and symbolic content of the work, the creative artist's will finds its expression. His spiritual essence and specificity of an author's outlook, axiological orientations and subjective-personal meanings with the originality of artistic thinking are also considered.

Musical composition as a structured artistic integrity, endowed with a system of intonational meanings and symbols, is a special type of an artistic

${ }^{28}$ Devyatova O. (2012). Composer in the system of culture. Ekaterinburgh: Izdatel'stvo Uraljskogho unyversyteta. P. 9.

${ }_{29}$ Jampol'sjkyj I. (1974). Musical performance // Musical Encyclopedia. Vol. 2. Moscow: Soviet encyclopedia. P. 585.

${ }^{30}$ Ibid. Pp. 585-586. 
message, an artifact and a phenomenon of culture. "The fact it is not an impersonal "information", not a passive silent object of usage..., not a text, but a work of "an alien consciousness" - this makes it really the part of a culture" ${ }^{, 31}$.

The emergence of this artifact in the European tradition is predetermined by a new concept of a written musical culture, within which crystallizes fundamentally new "view of music as a composition with an internal structure and complex content organization that determines the fixation, not previously mandatory" ${ }^{\prime 2}$.

Composition bears the features of a composer's stylistic personality, is inseparable from a creator's figure and emphasizes his authorial "incomparability" (T. Cherednichenko). Creator embodies a new form of a music being and an image of an "artistic author" ${ }^{\text {, }}$, whose personality is ready to become more and more actualized.

Understanding of a composition as a composer's creative activity product, as a specific artistic reality and a self-estimable aesthetic integrity, distinguished by an individuality, exists in the form of a decorated music sheet and reproduced by the performers on the basis of the laws laid down by an author, staying the witness of a musical art's new era evolutionary development and composer's figure crystallization. A communicative system formation, attributable to the European musical culture, begins from the moment of alienation of musical texts from the author's figure, separation of a musician-creator and musician-performer functions. The dissemination of an individual creativity through a personalized compositions associated with an author's name, led to the establishment of the initiative composer's figure as a creative subject of culture.

A new form of an "Artifactual Music" being (G. Eggebrecht) ${ }^{34}$ in the form of unique, compositionally completed and written work, endowed with personal qualities, authorial status and embodied in the tradition of a "composer's music", is associated with an "opus" term and concept, originated during the late Renaissance treatise "Music" (XVI ${ }^{\text {th }}$ century). The emergence of an "opus" and its derivative "opus musik", which approved a new type of an original "created-recorded author's music", reflected a paradigmatic turn in the European musical consciousness from the

${ }^{31}$ Batkin L. (1985). About some conditions of the culturological approach // Antychnaya kul 'tura i sovremennaja nauka. Ancient culture and modern science. Moscow: Nauka. P. 304.

${ }^{32}$ Cherednichenko T. (1974) Musical aesthetics // Muzykal'naya entsiklopediya [Musical Encyclopedia]. Vol. 6. Moscow: Soviet encyclopedia. P. 555.

33 Kazanceva L. (1998). Author in a musical content. Astrakhan': Izdatel'skopolyghraficheskiy kompleks "Volgha".

${ }^{34}$ Eggebrecht H.-H. Opusmusic. Schweizerische Musikzeitung, 1975. № 1. P. 4. 
improvisation to composition, from the "culture of musical activity" to the "culture of musical composition". The establishment of this approach, according to E. Nazaykinsky, falls into the fifteenth century ${ }^{35}$.

The terminological crystallization of the "opus" term, which perpetuates the creator's name, triggered the idea of an "opusmusic" in the European musical culture, endowed with an authorial status and conceptualization of the composer's phenomenon. The first known opus example in European Renaissance music is the "Motecta festorum" op. 10 by L. Viadani (1597).

An opus specificity, hightlighted as a “...work, which after the author's death stays perfect..., opus perfectum et absolutum"36, according to $\mathrm{K}$. Dahlhaus, is characterized by a self-worth, fixedness (in the form of a written texts) and compositional completeness ${ }^{37}$.

The same position is occupied by G. Eggebrecht, according to his definition the opus is formed by subordination rules, spiritual and philosophical content presence, fixedness, authorship, uniqueness. The scientist considers elitism, involvement in the enlightened layer, specific theoretical character to be the most significant qualities of an opus music $^{38}$.

In a broad aesthetic sense, the opus is realized as a pan-European type of "a subject embodiment of a composer's activity, characterized by an orientation on the applied tasks implementation, canonization of an expressive means, written fixation of the composition in the music sheet..." ${ }^{39}$.

According to V. Martinov, the fact of a composition's designation as an opus began to consider as "a recognition of the composition's reality, which contributed to its legitimacy and further public existence" 40 .

Fixed author's musical composition (opus) in the historical and cultural context of the Renaissance began to fulfill a new functional role and social significance, acquired a special semantic concentration, different from a

${ }^{35}$ Nazajkynskyj E. (1982). Musical composition logic. Moscow: Muzyka. P. 20.

${ }^{36}$ Mdyvany T., Kholopova V. (ed) (2014). European music of an academic tradition: essence, origins, current state (on the example of Russian and Belarusian composers). Nacyonal'naya akademiya nauk Belarusi; Centr issledovanyya belaruskoi kul'tury, jazyka i lyteratury, fylyal instituta iskusstvoved., etnoghrafiyi i fol klora im. K. Krapivy. Minsk: Belaruskaya navuka. P. 127.

${ }^{37}$ Dahlhaus C Plädoyer für eine romantische kategorie. Der Begriff des Kunstwerks in der neuesten Musik. Neue Zeitschrift fur Musik, 1969, № 7-8. P. 20.

${ }^{38}$ Eggebrecht H.-H. Opusmusic. Schweizerische Musikzeitung, 1975. № 1. P. 4.

39 Keldysh Yu. V. (ed) (1991). Musical Encyclopedia Dictionary. Moscow: Soviet encyclopedia. P. 398.

${ }^{40}$ Martynov V. (2005). Opus Post Zone or the birth of a new reality. Moscow: Izdateljskij dom "Klassika - XXI". P. 9. 
common "time to time" creativity. The very status of a creativity result has changed - musical composition has passed from the applied sphere to the rank of self-created and autonomous creation and became to perceive as a cultural artifact, an independent and self-sufficient phenomenon, firmly linked to everything, which has an intonational "appearance".

According to N. Gerasimova-Persidska the motit of an ars Antiqua era, which is regarded as res facta, considered as a transient phenomenon on the path of a musical composition appearance (opus-musik). Despite its fixedness, structureness, and separate intertextual connections availability, awareness of "this motet", this "composition", the creation remains anonymous and variant, easily "transformed" into another variant ${ }^{41}$.

According to the researcher, - "The emergence of an authorship is associated with a great value and "uniqueness" of the sample... - a musical composition $^{42}$, which becomes a manifestation of a personal composer's traits. The research author points on a preserved in history name of one of the earliest musical composition's author - Petrus de Krutze, who sought to an original embodiment of an intonational voices content and general structural patterns.

\section{CONCLUSIONS}

The historical crystallization of a composer's and individual musical authorship phenomena has become a special landmark act in the panorama of European civilization cultural events. This dynamic cultural process, unfolded in the continuum of the Renaissance era (the content of which was determined by the anthropocentric world's picture), was determined by an objective factors of social, spiritual, aesthetic and artistic society development, also by the general musical culture evolutionary logic and occurred in parallel with:

- an affirmation of a universal personality concept, which became the Renaissance cultural dominant and defined the paradigm of its thinking;

- an individual authorship model formation;

- broadening of a world's outlook;

- the growth of an individuality origin in the art;

- self-determination of a music as an artistic cultural language and an independent form in the system of arts;

- tendency for musical culture professionalization and textualization.

${ }^{41}$ Gherasimova-Persydskaya N. (2002). From "res faskta" to "opus": process and structure // Muzychnyj tvir jak tvorchyj proces: zbirnik statey. Naukovyj visnyk nacional'noji muzychnoji akademiji Ukrajiny im. P. I. Chajkovsjkogho Musical work as a creative process. Scientific Bulletin of the National Music Academy of Ukraine. P. I. Tchaikovsky, Vol. 21. Pp. 3-10. P. 6.

${ }^{42}$ Ibid. P. 6. 
With his appearance in the European art space of the Renaissance, a composer, as an author's personality and a social being phenomenon, reflected the transition from oral, improvisational practice to a written (sheet music) culture and such type of a musical professionalism, which had an ability for creative tasks in the system "author-performer-listener" implementation.

In a course of musical art semantic evolution, the activity of a composer as a creative subject, carrier of European cultural text and academic musical traditions (based on the principles of spirituality and ethic-aesthetic values) representative, becomes an independent artistic realm and sphere of personal creativity.

The affirmation of composer's and musical authorship phenomena, the concept of a musical composition (opus music) associated with them, reflected paradigmatic changes in European spiritual consciousness and musical culture as an evolving artistic system.

\section{SUMMARY}

The subject of the study is the composer's phenomenon and the phenomenon of a musical authorship, considered in the historical and cultural context of the Renaissance. The purpose of the proposed reconnaissance is to understand the specific crystallization of the composer's phenomenon and the model of an individual musical authorship in the European cultural consciousness of the Renaissance.

The methodology of a research is based on a set of general scientific and special (art, including musical studies) approaches and methods. Among the scientific methods used in the research, the main are: historical, systemic, cultural, dialectical, phenomenological, etc.

The formation character of a music-author tradition is considered as a branch of a classical authorship concept, which prevails over collectivity and anonymity, formed in the Western European culture, and is caused by the new socio-cultural conditions, tendencies of secularization and of texts dissemination. The semantic role of the composer in the processes of a cultural formation and the world's musical picture modeling is highlighted and the specificity of an artistic system "author - creativity - composition" representation in the Renaissance music is determined.

It is emphasized in the summary that composer's figure crystallization and an individual musical authorship model appeared as a distinctive act (in the panorama of cultural events), determined by an objective factors of the spiritual, personal and cultural development of a human and society in the context of European civilization evolution. 


\section{REFERENCES}

1. Asaf'ev B. (1971). Muzykal'naja forma kak process [Musical form as a process]. Kniga 1-2. Leninghrad: Music. (in Russian).

2. Batkin L. (1985). O nekotorikh uslovyjakh kul'turologhicheskogho podkhoda [About some conditions of the culturological approach] // Antychnaya kul'tura i sovremennaja nauka. Ancient culture and modern science. Moscow: Nauka. Pp. 303-312. (in Russian).

3. Batkin L. (1989). Italiyanskoe vozrozhdenye $v$ poiskakh individual'nosti [Italian Renessance in a search of personality]. Moscow: Nauka. (in Russian).

4. Dahlhaus C. (1969) Plädoyer für eine romantische kategorie. Der Begriff des Kunstwerks in der neuesten Musik. Neue Zeitschrift fur Musik, no. 7-8. pp. 18 -22. (in Germany).

5. Devyatova O. (2012). Kompozitor v sisteme kul'tury [Composer in the system of culture]. Ekaterinburgh: Izdatel'stvo Uraljskogho unyversyteta. (in Russian).

6. Eggebrecht H.-H. (1975).Opusmusic. Schweizerische Musikzeitung, no. 1. pp. 2 -11. (in Schweiz).

7. Gherasimova-Persydskaya N. (2002). Ot "res fakta" $k$ "opusu”: process $i$ struktura [From "res faskta" to "opus": process and structure] // Muzychnyj tvir jak tvorchyj proces: zbirnik statey. Naukovyj visnyk nacional'noji muzychnoji akademiji Ukrajiny im. P. I. Chajkovs'kogho Musical work as a creative process. Scientific Bulletin of the National Music Academy of Ukraine. P.I. Tchaikovsky, vol. 21. Pp. 3-10. (in Ukrainian).

8. Ghoral'skij A. (2002). Teoriya tvorchosti [Creativity theory] / Pereklad z pol's'koji; O. Ghirnyj. L'viv: Kamenjar; Varshava: Universitas Rediviva. (in Ukrainian).

9. Grom'jak R., Kovaliv Yu., Teremko V. (ed) (2007). Literaturoznavchyj slovnyk-dovidnyk. [Literary references dictionary]. Kyiv: VC "Akademija". (in Ukrainian).

10. Gruber R. (1965). Vseobshchaya istoriya muzyki [General History of Music]. Moscow: Music. (in Russian).

11. Ivanova L. (2006). Kompozytor: ocherky po ystoryy stanovlenyja professyi [Composer: essays on the history of the professional formation]. (PhD Thesis). Moskva: MGhK im. P. Y. Chajkovskogo. (in Russian).

12. Kazanceva L. (1998). Avtor v muzykal'nom soderzhanii [Author in a musical content]. Astrakhan': Izdatel'sko-polyghraficheskiy kompleks "Volgha". (in Russian).

13. Kaloshyna Gh. (2001). Khrystyjanskaya tematika i problemy zhanrovoj evoljuciyi francuzskoj operi i oratoriyi: ot ystokov $k X X$ stoletiu [Christian subjects and problems of the genre evolution of French opera and oratoria: from the 
beginnings to the twentieth century] // Muzykal'naya kul'tura khrystyanskogho mira: materialy mezhdunar. nauchnoi konferenciyi. The musical culture of the Christian world. Rostov n/D: izdatel'stvo Rostovskoj gosudarstvennoy konservatoriyi im. S. V. Rakhmaninova, pp. 297-316. (in Russian).

14. Keldysh Yu. V. (ed) (1991). Muzykal'nyi entsiklopedicheskii slovar [Musical Encyclopedia Dictionary]. Moscow: Soviet encyclopedia. (in Russian).

15. Konovalova I. (2018). Fenomen kompozytora $v$ chasoprostori jevropejs'koji muzychnoji kul'tury XX stolittja: modusy teoretuchnogho osjaghnennja: monoghrafiya. [The Composer Phenomenon in the 20th century European Music Cultural Space: Modes of Theoretical Understanding]. Kharkiv: TOV "Planeta-Print". (in Ukrainian).

16. Kyjanovs'ka L. (2012). Obraz kompozytora v suspil'stvi [Composer's image in society] // Naukovyj visnyk Nacional'noji muzychnoji akademiji Ukrajiny im P.I. Chajkovs'kogho. Scientific Bulletin of the National Music Academy of Ukraine named after P. I. Tchaikovsky. Vol. 75. Kyiv: NMAU, pp. 25-35. (in Ukrainian).

17. Livanova T. (1986). Istoriya zapadnoevropeyskoy muzyki do $1789 \mathrm{~g}$. [The history of Western European music until 1789]. Vol. 1 : Ot antichnosti k XVIII veku [From Antiquity to the 18th Century]. Moscow: Music. (in Russian).

18. Lozovoi V. (2007). Morfologhija kul'tury: tezaurus. [Culture morphology: thesaurus]. Kharkiv: Pravo. (in Ukrainian).

19. Malkov S. (2010). Koncepciyi avtorstva y zadachi sistemy obrazovanyja [Concepts of an authorship and tasks of an educational system] // Chelovek vchera i seghodnja: mezhdyscyplynarnye issledovanyja. Man yesterday and today: interdisciplinary research vol. 4. Moscow: Institut filosofyy RAN, pp. 39-50. (in Russian).

20. Martynov V. (2005). Zona Opus Post ili rozhdenie novoj real 'nosty. [Opus Post Zone or the birth of a new reality]. Moscow: Izdateljskij dom "Klassika - XXI". (in Russian).

21. Mdyvany T., Kholopova V. (ed) (2014). Evropejskaja muzyka akademycheskoj tradycyii: sushhnost', istoky, sovremennoe sostojanie (na primiere tvorchestva kompozitorov Rossiyi I Belarusi) [European music of an academic tradition: essence, origins, current state (on the example of Russian and Belarusian composers)]. Nacyonal'naya akademiya nauk Belarusi; Centr issledovanyya belaruskoi kul'tury, jazyka i lyteratury, fylyal instituta iskusstvoved., etnoghrafiyi i fol'klora im. K. Krapivy. Minsk: Belaruskaya navuka. (in Belarus).

22. Nazajkynskyj E. (1982). Loghyka muzykal'noj kompozycii. [Musical composition logic]. Moscow: Muzyka. (in Russian). 
23. Semenov O. (1978). Vzaimootnoshenie avtora, proyzvedenyja y zritelja (chytatelja, slushatelja) [The relationship of an author, composition and viewer (reader, listener)] // Muzikal'noye iskusstvo i nauka, Vol. 3. Musical art and science. Moscow: Muzika, pp. 78-105. (in Russian).

24. Simakova N. (1985). Vokal'nye zhanry epokhi Vozrozhdenya. [Renaissance vocal genres]. Moscow: Muzika. (in Russian).

25. Cherednichenko T. (1989) Tendenciyi sovremennoi zapadnoi muzykal'noi estetiki. [Trends of Contemporary Western Musical Aesthetics]. Moscow: Muzika. (in Russian).

26. Cherednichenko T. (1974) Estetika muzikal'naja [Musical aesthetics] // Muzykal'naya entsiklopediya [Musical Encyclopedia]. Vol. 6. Moscow: Soviet encyclopedia, pp. 554-566. (in Russian).

27. Shapovalova L. (2001). O dvukh tipakh lichnosti: k opredelenyju refleksiyi v muzyke [About two types of personality: to musical reflection definition] // Muzykaln'aya kult'ura khrystyanskogho mira: materialy mezhdunar. nauchnoi konferenciyi. The musical culture of the Christian world. Rostov n/D: izdatel'stvo Rostovskoj gos. konservatoriyi im. S. V. Rakhmaninova, pp. 133 - 140. (in Russian).

28. Shestakov V. (1975). Ot etosa k affektu. Istoryja muzukal'noi estetiki ot antichnosti do XVIII veka: issledovanie. [From ethos to affect. The History of Musical Aesthetics from Antiquity to the 18th Century]. Moscow: Muzika. (in Russian).

29. Jampol'sjkyj I. (1974). Ispolnenie muzykal'noe [Musical performance] // Muzykal'naya entcyklopediya [Musical Encyclopedia]. Vol. 2. Moscow: Soviet encyclopedia. pp. 583-591. (in Russian).

\section{Information about the author:} Iryna Konovalova,

Doctor of Art criticism (hab.dr), Docent, Associate professor at the Department of History and Theory of Music Kharkiv State Academy of Culture, Kharkiv 4, Bursatski Uzviz, Kharkiv, 61057, Ukraine orcid.org/0000-0003-0133-1816 